\title{
How Veblenian Evolutionary Thinking Transcends Methodological Individualism and Methodological Collectivism
}

Geoffrey M. Hodgson

\section{(2) OpenEdition Journals}

Electronic version

URL: http://journals.openedition.org/ei/5782

DOI: $10.4000 /$ ei.5782

ISSN: 2553-1891

Publisher

Association Économie et Institutions

\section{Printed version}

Date of publication: 1 December 2003

Number of pages: 5-28

ISSN: 1775-2329

\section{Electronic reference}

Geoffrey M. Hodgson, « How Veblenian Evolutionary Thinking Transcends Methodological Individualism and Methodological Collectivism », Économie et institutions [Online], 3 | 2003, Online since 31 January 2013, connection on 20 April 2019. URL : http://journals.openedition.org/ei/5782 ; DOI : 10.4000/ei.5782 


\title{
How Veblenian Evolutionary Thinking Transcends Methodological Individualism and Methodological Collectivism
}

\author{
Geoffrey M. Hodgson ${ }^{1}$
}

The term 'evolutionary economics' describes a wide variety of views and approaches, some of which do not embrace ideas or analogies from biology. ${ }^{2}$ Nevertheless, the use of Darwinian mechanisms of variation, inheritance and selection is now quite widespread among evolutionary economists. However, the importance of Darwinism for economics involves more than mere analogy. The leading biologist and philosopher of biology Ernst Mayr (1964, p. xviii) rightly remarked: 'It has taken 100 years to appreciate fully that Darwin's conceptual framework is, indeed, a new philosophical system.' The philosophical aspects of Darwinism are now more widely appreciated. A survey of about one thousand academic philosophers organised by the Philosopher's Magazine put Darwin's Origin of Species as the third most important book in philosophy ever, after Plato's Republic and Kant's Critique of Pure Reason. ${ }^{3}$

It is a purpose of this paper to consider some of the philosophical implications of Darwinism to the social sciences, particularly concerning methodological individualism and methodological collectivism. Over a hundred years ago, Thorstein Veblen used Darwinian ideas to begin the transformation of economics into an evolutionary science. This essay shows how Veblen did this, and considers the methodological implications. Veblen's Darwinian position is established as quite different from both methodological individualism and methodological collectivism.

This paper is organised in four sections. The first section explores the meaning of Darwinism and its relevance for the social sciences. The second section shows how Veblen applied Darwinian principles to economics. The third section show how Veblen, in line with these principles, implicitly ruled out both methodological

${ }^{1}$ The Business School, University of Hertfordshire, Mangrove Road, Hertford, Hertfordshire SG13 8QF, UK,

http://www.herts.ac.uk/business/esst/Staff/g-hodgson/hodgson.html http://www.geoffrey-hodgson.ws

Address for correspondence: Malting House, 1 Burton End, West Wickham, Cambridgeshire CB1 6SD, UK; g.m.hodgson@herts.ac.uk

2 This essay makes use of material from Hodgson (2004). The author is very grateful to an anonymous referee and many others for discussions and comments.

3 The Guardian, 21 September 2001

Economie et Institutions $-n^{\circ} 3-2^{e}$ semestre 2003 
individualism and methodological collectivism. Contrary to widespread supposition, Veblen did not explain individual behaviour in terms of social structures alone. The fourth section concludes this essay.

\section{The meaning of Darwinism}

Darwin did not only proclaim that species had evolved, but also pointed to the causal mechanisms of evolution. Darwin's life work was marked by an ambition to extend the realm of causal explanation into areas that were deemed taboo by religious doctrine. Darwin rejected explanations of natural phenomena in terms of design, to focus instead on the detailed physical or 'efficient' causes that had cumulated in the emergence of elaborate phenomena over long periods of time.

Darwin was aware that his Origin of Species offered far from a complete explanation of all aspects of evolution, and expressed a profound ignorance of the mechanisms that led to variations in organisms (Darwin, 1859, p. 167). But he did not believe that variations emerged spontaneously, in the sense of being without a cause. Darwin (1859, p. 209) asserted that such 'accidental variations' must be 'produced by ... unknown causes' rather than embracing a notion of a spontaneous, uncaused event.

Darwin believed that relatively simple mechanisms of cause and effect could, given time and circumstances, lead to amazingly complex and varied outcomes. Darwin upheld that complex outcomes could be explained in terms of a detailed succession and accumulation of step-by-step causal mechanisms. Darwin $(1859$, p. 43) wrote of the supreme importance of 'the accumulative action of Selection'. Darwin's famous maxim, 'natura non facit saltum' (nature does not make leaps) was in part an appeal to this method of detailed, sequential causal explanation. Darwin did not simply argue that natural selection worked slowly, he also - and more importantly - upheld that each step was susceptible to causal explanation.

This doctrine applied to the most sophisticated and complex outcomes of evolution, such as the eye and human consciousness. Accordingly, there were neither sudden nor miraculous leaps in the evolution of human intentionality. Like all human attributes, they must have been prefigured in the species from which humans are descended. In this way the causal origin of these features is susceptible to explanation. Darwin $(1859$, p. 208) thus wrote: 'A little dose ... of judgement or reason often comes into play, even in animals very low in the scale of nature.'

Darwin's devoted follower, Thomas Henry Huxley, had similar views to Darwin concerning causality and the aims of science. For 
Huxley the idea of uncaused and spontaneous event was absurd and unacceptable. Science was nothing less than an ongoing endeavour to reveal the causes behind phenomena. Huxley (1894, vol. 1, pp. 158-9) wrote:

"any one who is acquainted with the history of science will admit, that its progress has, in all ages meant, and now, more than ever, means, the extension of the province of what we call matter and causation, and the concomitant gradual banishment from all regions of thought of what we call spirit and spontaneity."

Similarly, George Romanes - a friend of Darwin and Huxley also insisted that Darwinism above all meant causal analysis. For Romanes (1893, p. 5), taxonomy and the accumulation of facts were the means, but not the goal, of science. 'Not facts, then, but causes or principles are the ultimate objects of scientific quest.' In another passage, Romanes explained that a goal of Darwinism was to extend the type of causal explanation that was applicable to mechanical phenomena into the organic world. Romanes (1893, p. 402) argued that Darwinism

"seeks to bring the phenomena of organic nature into line with those of inorganic; and therefore to show that whatever view we may severally take as to the kind of causation which is energizing in the latter we must now extend to the former. ... the theory of evolution by natural selection ... endeavours to comprise all the facts of adaptation in organic nature under the same category of explanation as those which occur in inorganic nature - that is to say, under the category of physical, or ascertainable, causation."

Darwinism brought not only human evolution, but also the human mind and consciousness within the realms of science. Much of human physiology could be explained by natural selection; Darwinism thus brought the frontier of scientific enquiry to the inner workings of the human mind.

Darwinism is rightly associated with the ideas of variation, inheritance and selection. However, underlying this theory of evolution are philosophical principles that are even more fundamental to Darwinism. At this point it would be useful to clarify and take stock of these five key Darwinian philosophical principles.

(1) The principle of determinacy. This is otherwise known in philosophy as 'the principle of universal causation' or sometimes 'ubiquity determinism'. Its rough and ready expression is 'every event has a cause', and more precisely, everything is determined in accordance with laws by something else.

The principle of determinacy does not imply that events are necessarily predictable, or that any one set of events will always lead to the same, regular outcome. These versions of 'determinism' are not adopted here. Furthermore, the principle of determinacy does not 
imply a 'mechanistic' view. 'Mechanistic' views are said to exclude intentionality, but intentionality is here acknowledged and included. The principle of determinacy upholds that intentions are caused, but this does not diminish the reality or responsibility of will or choice. ${ }^{4}$

(2) The doctrine of continuity. A species is a causal and evolutionary outcome of accumulated gradations and variations, with organisms that inherit and preserve most of their characteristics through time. It is upheld that complex outcomes are the result of accumulated, incremental changes. Miraculous leaps and teleological determination are excluded. This means that human intentionality has itself evolved gradually through time. In general, continuity involves mechanisms of inheritance upon which slight generational variations are accumulated.

(3) Cumulative causal explanation. The idea of causal explanation is applied sequentially to these step-by-step developments. Accordingly, their explanation involves tracing this causal process by focusing on its key processual algorithms. Even if every step in the process cannot be determined in detail; the exploration of the algorithmic process helps to provide an explanation. The key algorithmic process emphasised by Darwin was natural selection. However, the concept of selection in Darwinism necessarily invokes neither competition nor militant struggle.

(4) The principle of evolutionary explanation. It follows from the above that any behavioural assumption, including in the social sciences, must be capable of cumulative causal explanation in evolutionary terms, or at least be consistent with a scientific understanding of human evolution. Other sciences are not mere extensions of biology: but they must be consistent with an acceptable version of it. In particular, if there are biological constraints or influences on human capacities or behaviours, then they should be neither contradicted nor negated by assumptions at the psychological or social levels.

(5) The principle of consistency of the sciences. This is a generalisation of the sixth principle: any scientific assumption or principle at a specific ontological level must be consistent with a scientific understanding of all lower ontological levels. For example, the social sciences are not reducible to psychology, biology, chemistry or physics, but they must be consistent with acceptable versions of these sciences.

There are other Darwinian ontological principles that there is not the space to explore here. Among these are Darwin's 'population thinking' (Mayr, 1964, 1988, 1992) and an approach that Bunge

4 Notably, in his early works, Dewey $(1910,1922)$ elaborated a similar position, as discussed in Hodgson (2004). 
(1980) has described as 'emergentist materialism'. Emergentist materialism rejects multiple and independent forms of being, where one type of substance (notably mind) is treated as entirely separate from and independent of another (notably matter); the mental level is understood in terms of emergent properties of organised matter.

What has been argued here is that Darwinism itself presupposes several important ontological methodological presuppositions. These presuppositions apply to the socio-economic as well as the biological realm. We now examine the way in which Veblen understood and applied these Darwinian ideas.

\section{Veblen's application of Darwinism to economics}

Veblen (1898a, p. 393) wrote: 'an evolutionary economics must be a theory of a process of cultural growth as determined by the economic interest, a theory of a cumulative sequence of economic institutions stated in terms of the process itself.' In a key passage, Veblen (1899, p. 188) declared:

"The life of man in society, just like the life of other species, is a struggle for existence, and therefore it is a process of selective adaptation. The evolution of social structure has been a process of natural selection of institutions. The progress which has been and is being made in human institutions and in human character may be set down, broadly, to a natural selection of the fittest habits of thought and to a process of enforced adaptation of individuals to an environment which has progressively changed with the growth of community and with the changing institutions under which men have lived. Institutions are not only themselves the result of a selective and adaptive process which shapes the prevailing or dominant types of spiritual attitude and aptitudes; they are at the same time special methods of life and human relations, and are therefore in their turn efficient factors of selection. So that the changing institutions in their turn make for a further selection of individuals endowed with the fittest temperament, and a further adaptation of individual temperament and habits to the changing environment through the formation of new institutions."

It was no accident that Darwin's phrases 'natural selection' and 'struggle for existence' appeared here. Veblen (1899, p. 207) wrote also in the same work of the law of natural selection, as applied to human institutions'. Apparently without of the knowledge of David Ritchie's (1896) similar insight, Veblen became the second writer after the publication of the Origin of Species to apply with 
some rigour Darwin's principle of selection to the evolution of customs and institutions.

"The decisive implication here was to open up the possibility that Darwinism could be applied to human society without necessarily reducing explanations of social phenomena entirely to individual psychology or biology. Once we consider the natural selection of institutions, and in turn treat institutions as emergent properties in the social realm, then that road is opened."

Veblen also appreciated the philosophical underpinnings of Darwinism. There is abundant evidence that Veblen understood Darwinism most fundamentally in terms of a commitment to detailed and sequential causal analysis. For example, Veblen (1898a, pp. 375-8) wrote:

"Any evolutionary science ... is a close-knit body of theory. It is a theory of a process, of an unfolding sequence ... of cumulative causation. The great deserts of the evolutionist leaders ... lie ... in their having shown how this colorless impersonal sequence of cause and effect can be made use of for theory proper, by virtue of its cumulative character."

This insistence on explanation in terms of a cumulative causal sequence was repeated in several works (Veblen, 1898a, pp. $381,384,386 ; 1900$, p. 266; 1904, pp. 67, 313, 314, 365). Although Darwin himself did not use the term 'cumulative causation', it is important to underline the way that Veblen saw it as linked with Darwinism. In some passages, Veblen $(1904$, p. 370) made the link with Darwin explicit:

"His [Darwin's] inquiry characteristically confines itself to the process of cumulative change. His results, as well as his specific determination of the factors at work in this process of cumulative change, have been questioned; perhaps they are open to all the criticisms levelled against them as well as a few more not thought of; but the scope and method given to scientific enquiry by Darwin and the generation whose spokesman he is has substantially not been questioned, except by that diminishing contingent of the faithful ..."

Veblen's key point of emphasis was one of causal sequence. Veblen $(1919$, p. 37) visited this theme persistently, as in this essay of 1908:

"The characteristic feature by which post-Darwinian science is contrasted with what went before is a new distribution of emphasis, whereby the process of causation, the interval of instability and transition between initial cause and definitive effect, has come to take the first place in the inquiry; instead of that consummation in which causal effect was once presumed to come to rest. This change in point of view was, of course, not abrupt or catastrophic. But it has latterly gone so far that modern 
science is becoming substantially a theory of the process of consecutive change, realized to be self-continuing or selfpropagating and to have no final term."

In the same year Veblen (1908, p. 159 n.) wrote of the field of cumulative change within which the modern post-Darwinian sciences live and move and have their being.' Only a few commentators on Veblen have recognised this crucial Darwinian focus on causal processes in Veblen's writings. As Karl Anderson (1933, p. 602) put it, modern science for Veblen 'demands an explanation of things in terms of cause and effect, and postulates that the causal relationship has neither starting-point nor stoppingpoint but runs in an endless sequence.' Similarly, Idus Murphree (1959, p. 312) remarked that Veblen 'thought of the Darwinian method as one that revealed the impersonal sequence of mechanical cause and effect and dispensed with a search for universal purposes and belief in a "natural order".'

Overall, in Veblen's writing there was the same emphasis on the detailed and processual nature of Darwinian evolution as in the modern work of Daniel Dennett (1995). Although Veblen did not use the same word, he had as much appreciation as Dennett of the nature of Darwinian evolution as an 'algorithmic' process. Veblen used phrases such as 'cumulative causation', 'theory of a process, of an unfolding sequence' and 'impersonal sequence of cause and effect' to connote the same idea. This focus on algorithmic processes is both revolutionary and highly modern; it directs attention to ongoing processes rather than static equilibria. ${ }^{5}$

However, while Veblen coined the term 'cumulative' causation, he used it primarily to refer to cumulative sequences of cause and effect. With other authors, the term 'cumulative causation' took on the different meaning (in modern parlance) of non-linear processes of positive feedback (Young, 1928; Kaldor, 1985; Myrdal, 1939).

Another prominent Darwinian theme in Veblen's writings was his attempt to reconcile the reality of human will and intentionality with science and causal explanations. Veblen neither denied nor

\footnotetext{
5 However, the differences in approach between Dennett and Veblen should not be overlooked. For example, Dennett's (1995) devotion to the vague concept of the 'meme' as the unit of cultural evolution contrasts with Veblen's pragmatist insistence on habit as the basis of ideas and essence of culture and his emphasis on emergent institutions as units of selection. One of the problems with 'memetics' is that the causes of meme replication are unexplained, while Veblen explained the replication of institutions in terms of the psychological mechanisms of individual habit formation. Furthermore, Veblen's (1909a, p. 300) strictures against reductionism have no adequate parallel in Dennett (1995).
} 
underestimated the significance of human intentionality, but saw it as a result of evolution. Darwin rejected religious and teleological explanations of origin or destiny. Veblen rejected them too, while attempting to leave an intermediate place for 'teleology' in human purposeful behaviour. He retained the idea that persons were purposeful, but Veblen (1898b, pp. 180-93) placed this proposition within an evolutionary framework:

"Like other animals, man is an agent that acts in response to stimuli afforded by the environment in which he lives. Like other species, he is a creature of habit and propensity. But in a higher degree than other species, man mentally digests the content of habits under whose guidance he acts, and appreciates the trend of these habits and propensities. ... By selective necessity he is endowed with a proclivity for purposeful action. ... He acts under the guidance of propensities which have been imposed upon him by the process of selection to which he owes his differentiation from other species."

Hence Veblen followed Darwin and regarded human intentionality as a capacity that had itself evolved through natural selection. As Veblen (1899, p. 15) put it in another work, the capacity of humankind to act with deliberation towards ends was itself a result of natural selection:

"As a matter of selective necessity, man is an agent. He is, in his own apprehension, a centre of unfolding impulsive activity 'teleological' activity. He is an agent seeking in every act the accomplishment of some concrete, objective, impersonal end."

Despite this, Veblen is widely misunderstood as underestimating the actuality or significance of human intentionality and purposefulness. On the contrary, Veblen (1898a, p. 391) insisted: "Economic action is teleological, in the sense that men always and everywhere seek to do something.' The fact that such purposeful behaviour itself emerged through evolutionary selection does not mean a denial of the reality of purposeful behaviour. Instead, Veblen consistently tried to reconcile a notion of individual purposefulness (or sufficient reason) with his materialist idea of causality (or efficient cause).

Intentions can be causes, but intentions are always caused. The evolution of human intentionality, and its development within each human being, had to be explained in terms of materialist causes and evolutionary selection. As noted above, this is an aspect of the Darwinian doctrine of continuity. Accordingly, like Darwin, Huxley, Lewes and Morgan, Veblen rejected a dualist or Cartesian ontology that separated intentionality completely from matter and materialist causality. Veblen (1909b, pp. 624-5) saw such a dualism as unacceptable for the following reason: 
"The two methods of inference - from sufficient reason [or intention] and from efficient [or materialist] cause - are out of touch with one another and there is no transition from one to the other: no method of converting the procedure or the results of the one into those of the other."

Others since have echoed Veblen's argument against the idea of separate types of cause, and against the related Cartesian dualism of matter and mind. For example, Barry Hindess (1989, p. 150) asked pertinently: 'If human action is subject to two distinct modes of determination, what happens when they conflict, when intentionality pushes one way and causality pushes another?' We do not and cannot know the answer, because to reach it would involve the reconciliation of irreconcilables. John Searle (1997, pp. xii-xiii) similarly remarked: 'dualism ... seems a hopeless theory because, having made a strict distinction between the mental and the physical, it cannot make the relation of the two intelligible.' Mario Bunge (1980, p. 20) put it in a nutshell: 'Dualism is inconsistent with the ontology of science.'

Veblen perceived the consequences for the social sciences of this mistaken dualism. For example: 'The immediate consequence is that the resulting economic theory is of a teleological character "deductive" or "a priori" as it is often called - instead of being drawn in terms of cause and effect' (Veblen, 1909b, p. 625). His solution, following Darwin, was to place human intentionality in an evolutionary context. At least in principle, consciousness had to be explained in Darwinian and evolutionary terms. As Veblen (1906a, p. 589) alluded: 'While knowledge is construed in teleological terms, in terms of personal interest and attention, this teleological aptitude is itself reducible to a product of unteleological natural selection.' In the following passage, Veblen (1909b, p. 625) explained in more detail:

"The modern scheme of knowledge, on the whole, rests, for its definitive ground, on the relation of cause and effect; the relation of sufficient reason [or intention] being admitted only provisionally and as a proximate factor in that analysis, always with the unambiguous reservation that the analysis must ultimately come to rest in terms of cause and effect."

But this does mean that intentionality (or sufficient reason) is nonexistent or unimportant. On the contrary, Veblen (1909b, p. 623 n.) saw the existence of a 'rational faculty in man' as implying that 'the connection between stimulus and response is teleological'. Veblen (1909b, p. 625) acknowledged in similar terms that the relation of sufficient reason enters very substantially into human conduct. It is this element of discriminating forethought that distinguishes human conduct from brute behavior.' Veblen (1909b, p. 626) then went on to observe and approve that 'modern science at large has made the causal relation the sole ultimate ground of 
theoretical formulation'. Veblen saw 'the relation of sufficient reason as a proximate, supplementary, or intermediate ground, subsidiary, and subservient to the argument from cause to effect.'

In sum, while human intentionality is real and consequential, and a necessary element in any causal explanation in the social sciences, intentions themselves had also to be explained. As Veblen (1909b, p. 626) put it, explanation could not be confined to the 'rationalistic, teleological terms of calculation and choice' because the psychological beliefs and mechanisms that lay behind deliberation and preferences had also to be explained in terms of a 'sequence of cause and effect, by force of such elements as habituation and conventional requirements.' By embracing the need for such causal explanations, Veblen rejected both the assumption of the given individual in neoclassical economics and the opposite error of regarding human agency as entirely an outcome of mysterious social forces.

Veblen's position on intentionality has been the subject of some misunderstanding. David Seckler (1975, p. 56) came to the verdict that Veblen 'teeters between free will and determinism'. But Veblen acknowledged the reality of purposeful behaviour. While Seckler (1975, p. 86) accepted the 'methodological dualism' of Ludwig von Mises (1949) and others, Veblen (1898a, p. 386) argued in contrast that the dualist position of the Austrian school should be dissolved by bringing purposes and preferences within the orbit of scientific explanation. What Seckler failed to understand was that Veblen was trying to overcome the problems of dualism. Veblen was not trying to dispense with human will but to reconcile it with materialist causality. Veblen was trying to locate a different, more complex and more satisfactory position that rejected determinism in some of its versions, upheld the principle of determinacy, and saw human will as real but caused.

Veblen used the idea of an unbroken historical chain of cause and effect to undermine the presuppositions of mainstream economics. His use of Darwinian methodological injunctions led to a powerful critique. Ultimately, because the human agent was a subject of an evolutionary process, he or she could not be taken as fixed or given. A causal account of the interaction between the individual and social structure had to be provided. This causal account should not stop with the individual, but it should also attempt to explain the origin of psychological purposes and preferences.

Veblen argued that a problem with mainstream economics was that it provided a causal and evolutionary explanation neither of 'rational economic man' nor of his given preference function (Argyrous and Sethi, 1996; Hodgson, 1998). How did such rationality and preferences appear in human evolution? What causes and 
processes brought them into being? How and when are they formed in the development of each human individual? For Veblen, such an escape from evolutionary principles was impossible. Darwinism meant not only a critique of Divine intervention, but it also required a rejection of immanently conceived preference functions. As a result, the universal assumption in neoclassical economics 'of a passive and substantially inert and immutably given human nature' (Veblen, 1898a, p. 389) had to be criticised.

Veblen thus argued that utilitarian and hedonistic explanations of human behaviour were too limited, in part because they did not encompass an evolutionary and causal explanation of the origin of the assumed behavioural characteristics. The neoclassical assumption of given preferences side-steps an explanation of the origin and initial acquisition of those preferences. The assumption that individuals are selfish requires an explanation of the evolution of selfishness. In general, postulates about human behaviour at the socio-economic level themselves require explanation in evolutionary terms.

Veblen's criticism challenged the narrow definition of economics as 'the science of choice'. At a particular level of abstraction, it may be appropriate to consider the consequences of individual choices with fixed preferences, but the Darwinian perspective also obliges us eventually to consider the origin and evolution of those preferences. If economics is confined to fixed preferences, which are simply assumed at the outset, then it has to admit that it is limited in scope and that the narrow-defined 'economic approach' cannot explain everything. It would be better if the scope of economics were broadened, to include the explanation of the origin and variation of preferences themselves. Individual preferences have to be placed in the context of both individual development and the evolution of the human species.

Once we address human evolution, we must consider the possibility that at least some versions of 'rational economic man' would not emerge through evolutionary selection. As Veblen (1898b, p. 188) wrote with characteristic irony:

"But if this economic man is to serve as a lay figure upon which to fit the garment of economic doctrines, it is incumbent upon the science to explain what are his limitations and how he has achieved his emancipation from the law of natural selection."

Veblen rightly argued that if 'economic man' is assumed then his evolution must be explained. Veblen made the valid methodological injunction that any assumptions concerning the human agent must be capable of explanation in evolutionary terms: the assumptions of economics and other social sciences should consistent with Darwinism and our understanding of human evolution. This did not itself imply that all explanations had to be 
reduced to instincts. One of his underlying arguments is that any assumptions made concerning human nature or motivation should be consistent with those human attributes that have resulted from natural selection over hundreds of thousands of years. In this respect Veblen followed William James (1890), who made a supreme effort to reconcile psychology with the insights of Darwinism. Accordingly, Veblen upheld both the principle of evolutionary explanation and the principle of consistency of the sciences.

As well as the assumption of the given individual, the principle of evolutionary explanation also challenges the largely roledriven picture of the individual in much of twentieth-century sociology. If the individual were to be explained in terms of social roles, then it would be necessary to explain how those roles and the individual propensity to conform to them evolved. This would place role-driven sociology in some difficulty, as such an account would be forced to consider both the psychology of individual motivation and the individual and social mechanisms by which roles are created and reproduced. These aspects of social theory are subordinated if roles are made the drivers of action.

\section{The Rejection of Methodological Individualism and Methodological Collectivism}

Broadly, methodological individualism emphasises the human agent. Ludwig Lachmann (1969, p. 94) asserted that methodological individualism means that we shall not be satisfied with any type of explanation of social phenomena which does not lead us ultimately to a human plan.' But very few social scientists would deny the role of individual intentions in the explanation of social phenomena. In another attempt Jon Elster (1982, p. 453) defined methodological individualism as the doctrine that all social phenomena (their structure and their change) are in principle explicable only in terms of individuals - their properties, goals, and beliefs.' Being less banal, this definition also is not sufficiently precise, as it fails to clarify whether interactions between individuals or social structures are 'properties ... of individuals' or not. If individual interactions or social structures are not 'properties of individuals', then this narrower and more meaningful notion of methodological individualism can be deemed a failure, for the reasons given below.

Much of the confusion in the debate over methodological individualism stems from whether methodological individualism means explanations (a) in terms of individuals alone, or (b) in terms of individuals plus individual interactions or social structures. If it means (b), then few would disagree. If social structures or interactions between individuals are also an essential part of the doctrine, then it is misleading to give the individual exclusive 
representation in its chosen label. Such an inclusive notion would not warrant the title of methodological individualism any more than the description 'methodological structuralism'.

A more meaningful definition of methodological individualism is the injunction that socio-economic phenomena must be explained exclusively in terms of individuals. Methodological collectivism is symmetrically defined as the injunction that socio-economic phenomena must be explained exclusively in terms of socio-economic wholes, structures, institutions or cultures. Veblen used neither term, but implicitly rejected both doctrines.

Veblen's approach was to conceive of both agency and structure as a result of an evolutionary process. In particular, he saw human agency and purposefulness as a result of evolution at both biological and social levels. Purposeful behaviour was the result of both inherited instinct and the material and cultural environment within which the individual is situated. These led to the formation of habits, which acted as the grounding of purposes and beliefs.

Methodological individualism, in the more meaningful sense, ultimately requires the assumption that individuals are given (Hodgson, 1988). If individuals are not taken as given, then they too must be explained, and this either undermines explanations in terms of individuals alone, or leads to an infinite regress. Hence Veblen's critique of the notion that individuals should be taken as a given in social science undermines methodological individualism.

One of Veblen's clearest statements of his general position on methodological individualism and methodological collectivism was made in his article on 'The Limitations of Marginal Utility' in the Journal of Political Economy. Because of its importance regarding this central methodological question in social theory, the relevant passage will be quoted almost in its entirety. Veblen (1909b, pp. 628-9) started by pointing out that the assumption of given individuals under given institutional conditions would lead to static outcomes:

Evidently an economic inquiry which occupies itself exclusively with the movements of this consistent, elemental human nature under given, stable institutional conditions - such as is the case with the current hedonistic economics - can reach statical results alone; since it makes abstraction from those elements that make for anything but a statical result.

Veblen (1909b, p. 629) then made it clear that institutions serve not merely as constraints, but also they affect the very wants and preferences of individuals themselves:

"Not only is the individual's conduct hedged about and directed by his habitual relations to his fellows in the group, but these relations, being of an institutional character, vary as the institutional scene varies. The wants and desires, the end and the aim, the ways and the means, the amplitude and drift of the 
individual's conduct are functions of an institutional variable that is of a highly complex and wholly unstable character."

This statement amounts to a strong assertion of the reconstitutive power of institutions over individuals. Institutional changes affect individual 'wants and desires'. Preferences are endogenous, rather than exogenously given. Nevertheless, he acted immediately to forestall any misunderstanding that this strong downward causation amounted to a methodological collectivism. He did not believe that the social wholes entirely determine the individual parts. Veblen (1909b, p. 629) made it absolutely clear that the individual was still causally effective, that institutions were a product of individuals in a group, and institutions could not exist without individuals:

"The growth and mutations of the institutional fabric are an outcome of the conduct of the individual members of the group, since it is out of the experience of the individuals, through the habituation of individuals, that institutions arise; and it is in this same experience that these institutions act to direct and define the aims and end of conduct. It is, of course, on individuals that the system of institutions imposes those conventional standards, ideals, and canons of conduct that make up the community's scheme of life. Scientific inquiry in this field therefore, must deal with individual conduct and must formulate its theoretical results in terms of individual conduct."

However, the above passage does not amount to an assertion of methodological individualism, as defined here. Instead, Veblen upheld that individuals could not be removed from the picture, and he placed the individual in its social context. Veblen (1909b, pp. 62930) insisted that a complete and detailed causal explanation - that is what he meant by 'a genetic theory' 6 - means an explanation of how the individual acquires relevant habits of thought and behaviour:

"But such an inquiry can serve the purposes of a genetic theory only if and in so far as this individual conduct is attended to in those respects in which it counts toward habituation, and so toward change (or stability) of the institutional fabric, on the one hand, and in those respects in which it is prompted and guided by the received institutional conceptions and ideals on the other hand."

\footnotetext{
6 Explaining this, Veblen (1903, p. 655) wrote: 'This method is the genetic one, which deals with the forces and sequence of development and seeks to understand the outcome by finding how and why it has come about. The aim is to organize social phenomena into a theoretical structure in causal terms.' Clearly, this has nothing to do with the modern concept of the gene.
} 
Veblen (1909b, p. 630) then went on to criticise those mainstream economists who 'disregard or abstract from the causal sequence of propensity and habituation in economic life and exclude from theoretical inquiry all such interest in the facts of cultural growth'. By emphasising 'cumulative causation' and 'continuity of cause and effect' Veblen broke from any idea that explanations could ultimately be reduced to one type of entity or level. No such reduction is admissible within his Darwinian framework because all such elements have themselves to be explained in causal terms. As the philosopher of biology Elliott Sober (1981, p. 95) put it: 'Causality, in virtue of its transitivity, gives aid and comfort neither to the holist nor to the individualist. The causal chain just keeps rolling along.'

In sum, by rejecting both the individual and society as the ultimate unit of explanation, Veblen distanced himself from both methodological individualism and methodological collectivism. His solution was to adopt an evolutionary framework of explanation. Above all, Veblen's position does not give solace to any form of (biological, cultural, structuralist or individualist) reductionism.

Veblenian institutionalism shares with several other modern perspectives - including critical realism (Archer, 1995; Bhaskar, 1989) and structuration theory (Giddens, 1984) - the endorsement of the following four propositions:

(a) The dependence of social structures upon individuals. Social structures would not exist if individuals ceased to exist. Individuals through their actions may create, confirm, reproduce, replicate, transform or destroy social structures, either intentionally or unintentionally.

(b) The rejection of methodological individualism. Nevertheless, social structures cannot be explained entirely in terms of individuals and their relations. They are not reducible, in an ontological or an explanatory sense, to individuals alone.

(c) The dependence of individuals upon social structures. For their socialisation, survival and interaction, individuals depend upon social structures, and individual behaviour is significantly affected by its socio-structural context.

(d) The rejection of methodological collectivism. Nevertheless, individual behaviours cannot be explained entirely in terms of the social structures in which they are located. Such reductionist explanations are invalid.

These four propositions are implicit in the writing of Veblen. These four propositions amount to the notion that individuals and social structure are mutually constitutive. These four propositions are elemental for any viable and non-reductionist social theory. But much more is required, including an attempt to give these propositions some theoretical flesh and blood. 
In addition, Veblen shared with Auguste Comte, Karl Marx, George Henry Lewes, Émile Durkheim and others the insight that we are born into a world of many institutions that are not of our making. Hence there is a temporal asymmetry: although structures depend for their existence on a group of individuals, for each single individual, several structures precede agency. However, this insight rules out the central conflation of Giddens (1984) where actor and structure are seen as facets of a combined process. Giddens's structuration theory treats structure and agency as not only mutually constitutive but also conjoined. On the contrary, while people can change and be changed by social structures, they do not choose or create the structures and institutions into which they are born. Agents and structures are not different aspects of the same things or processes but different entities.

Veblen recognised this temporal asymmetry and thereby the weight of the past on human decisions and actions. For example, Veblen (1898a, p. 392-3) wrote of economic evolution in the following terms:

"the base of action - the point of departure - at any step in the process is the entire organic complex of habits of thought that have been shaped by past processes. The ... expression of each is affected by habits of life formed under the guidance of all the rest."

Similarly, in The Theory of the Leisure Class Veblen (1899, p. 191) argued:

"The institutions - that is to say the habits of thought - under the guidance of which men live are in this way received from an earlier time; more or less remotely earlier, but in any event they have been elaborated in and received from the past."

Again, Veblen (1914, pp. 6-7) explained in The Instinct of Workmanship:

"The apparatus of ways and means available for the pursuit of whatever may be worth seeking is, substantially all, a matter of tradition out of the past, a legacy of habits of thought accumulated through the experience of past generations."

By rejecting the unexplained given individual as a fundamental explanatory unit, Veblen focused on the weight of the past on individual expectations and choices. Veblen (1915, p. 132) thus wrote of the 'restraining dead hand' of the past. To take the individual as given would be to amputate this aspect of the past; to take institutions as given would cut off another causal process. The Veblenian restoration of the mechanisms by which the past bears upon the present has major implications for economic and social theory. It demarcates the whole tradition of institutional economics not only from the mainstream assumption of given preference functions, but also from those in the Keynesian tradition who 
emphasise expectations of the future without also paying heed to the formation of expectations by means of understandings and cognitions acquired in the past (Hodgson, 1988). To take stock at this point, we note Veblen's concordance with a fifth proposition for social theory:

(e) The temporal priority of society over any one individual. Individual interactions with society are engagements with something already made. In this sense, several social structures pre-date any one individual. As individuals we do not make society: it is there in some form at our birth, bearing the marks of the past practices of former generations. This temporal cleavage establishes social structures and society as entities distinct from individuals (or mere aggregates of individuals), at least because of the structural legacy bequeathed by past actors, and separates structure and agency as distinct but interconnected objects of investigation.

Social structures can be changed, but the starting point is not of our choosing. This fifth proposition breaks the conceptual symmetry of actor and structure and opens the door to time and history (Archer, 1995). Several modern social theorists would endorse the five propositions above: they are also consistent with some versions of Marxism.

For Veblen, institutions were outcomes of individual habituations and interactions, but exhibited distinctive properties that were not reducible to the properties of individuals themselves.

Furthermore, Veblen (1899, p. 212) considered the powers of an institution over individuals in the following terms:

"So soon as it has won acceptance as an authoritative standard or norm of life it will react upon the character of the members of the society which has accepted it as a norm. It will to some extent shape their habits of thought and will exercise a selective surveillance over the development of men's aptitudes and inclinations. The effect is wrought partly by a coercive, educational adaptation of the habits of all individuals, partly by a selective elimination of the unfit individuals and lines of descent."

In recognising that institutions can 'shape ... habits of thought' and enforce a 'coercive, educational adaptation' on individuals, Veblen was adopting a strong and reconstitutive sense of what today is called 'downward causation' (Campbell, 1974; Sperry, 1991; Hodgson, 2003, 2004). Veblen (1899, p. 246) repeated this idea in several places, writing for instance that the scheme of life, of conventions, acts selectively and by education to shape the human material'.

The idea of downward causation has been criticised for supposing that higher-level processes somehow cause lower-level physical laws to be violated (Kim, 1993). In terms of the interaction of 
agency and social structure, objections would rightly be raised against the idea of 'social forces' or 'economic laws' themselves acting directly upon the intentions of agents. If the social or cultural can affect the individual, then it does so through causes that operate upon the individual at the psychological level. If it is to be acceptable, the concept of reconstitutive downward causation does not rely on unexplained or mysterious types of cause or causality.

In clarifying his position, Nobel Laureate Roger Sperry (1991, p. 230) rightly insisted that the higher-level phenomena in exerting downward control do not disrupt or intervene in the causal relations of the downward-level component activity'. We are thus obliged to explain particular human behaviour in terms of causal processes operating at the individual level, such as individual aspirations, dispositions or constraints. Where higher-level factors enter, is in the more general explanation of the system-wide processes giving rise to those aspirations, dispositions or constraints.

Accordingly, at the level of the human agent, there are no magical 'cultural' or 'economic' forces controlling individuals, other than those affecting the dispositions, thoughts and actions of individual human actors. People do not develop new preferences, wants or purposes because mysterious 'social forces' control them. Following Veblen, what have to be examined are the social and psychological mechanisms leading to such changes of preference, disposition or mentality. It is through these mechanisms that social power is exercised over individuals.

What does happen is that the framing, shifting and constraining capacities of social institutions give rise to new perceptions and dispositions within individuals. Upon new habits of thought and behaviour, new preferences and intentions emerge. But we need to know how habits are changed. Veblen $(1899$, p. 190, emphasis added) was specific about the psychological mechanisms involved: "The situation of today shapes the institutions of tomorrow through a selective, coercive process, by acting upon men's habitual view of things'.

The crucial point in the argument here is to recognise the significance of reconstitutive downward causation on habits, rather than merely on behaviour, intentions or preferences. Clearly, the definitional distinction between habit (as a propensity or disposition) and behaviour (or action) is essential to make sense of this statement. ${ }^{7}$ But a second point is also of vital significance. Habit and instinct are foundational to the human personality. Reason, deliberation and calculation emerge only after specific habits have

7 The case for defining habit as a disposition is made in Hodgson (2004), where others adopting this conception are listed. 
been laid down; their operation depends upon such habits. In turn, the development of habits depends upon prior instincts. Instincts, by definition, are inherited. Accordingly, reconstitutive downward causation upon instincts is not possible. Reconstitutive downward causation works by creating and moulding habits. Habit is the crucial and hidden link in the causal chain.

Clearly, institutions may directly affect our choices, by providing incentives, sanctions or constraints. For example, we decide to drive within the speed limit because we see a police patrol car on the road. However, the particular intention is explained in terms of the existing preference to avoid punishment. This explanation does not itself involve a reconstitutive process. In contrast, to provide a reconstitutive causal mechanism, we have to point to factors that are foundational to purposes, preferences and deliberation as a whole. This is where habits come in. By affecting habits, institutions can indirectly influence our purposes or preferences. As long as we can explain how institutional structures give rise to new or changed habits, then we have an acceptable mechanism of reconstitutive downward causation.

In this manner it is possible to overcome the dilemma between methodological individualism and methodological collectivism. By acting not directly on individual decisions, but on habitual dispositions, institutions exert downward causation without reducing individual agency to their effects. Furthermore, upward causation, from individuals to institutions, is still possible, without assuming that the individual is given or immanently conceived. Again and again Veblen described how institutional changes acted upon individual habits of thought and behaviour. The concept of habit was central to his understanding of how institutions affect individual dispositions and behaviour, and how social power is exercised.

The broader idea that social institutions can in some way affect individual purposes or preferences became thematic for institutional economics as a whole. For example, Wesley Mitchell (1924, p. 24) saw money as an institution that 'makes us all react in standard ways to the standard stimuli it offers, and affects our very ideals of what is good, beautiful and true.' John R. Commons (1934, p. 698) likewise made it clear that 'not only the physical framework of the body, but also the spiritual framework of the mind, becomes institutionally habituated to the dominant ways of doing things'. Although this broad idea is thematic for institutionalism it is not confined to it. For example, Alfred Marshall (1949, p. 76) wrote repeatedly in his Principles of the development of new activities giving rise to new wants'. But no one was more careful than Veblen to specify the causal mechanisms of habituation, through which institutions can affect the very personality of the individual. A 
general statement of reconstitutive downward causation follows. This sixth principle of social theory, is actually an extension of the principle (c) above:

(f) Reconstitutive downward causation. The causal powers associated with social structures may not simply impede or constrain behaviour, but may also affect and alter fundamental properties, powers and propensities of individuals. When an upper hierarchical level affects components at a lower level in this manner, this may be seen as a special and stronger case of 'downward causation' that we may term as reconstitutive downward causation. Those particular social structures that have the capacity for substantial, enduring and widespread reconstitutive downward causation upon individuals are termed institutions.

Principle (c) asserts that social structure can affect individual behaviour. Principle (f) goes further, by upholding that social structure can also affect the fundamental properties of the individual. Taken together, the third and sixth principles are the symmetrical reverse of the first principle; for the first principle upholds - less controversially - that individuals can help to reconstitute the fundamental properties of some social structures.

Overall, these six principles of social theory amount to the extension of evolutionary possibilities into the social domain. At the same time, they uphold that individuals and social structures are mutually constitutive, thus excluding both methodological individualism and methodological collectivism, as defined here.

\section{Conclusion}

This essay emphasises that Darwinism has important philosophical implications for the social sciences. These implications were recognised by Veblen more than a hundred years ago. In particular, Darwinism involves a commitment to causal explanations and evolutionary explanations of origin. These principles apply to, on the one hand, individuals and their preferences, and on the other hand, social structures. Accordingly, any approach that takes either individuals or social structures as given is inadequate. In this way, Veblenian economics rules out both methodological individualism and methodological collectivism, at least in the manner defined here. On the positive side, Darwinism points to the application of principles of selection and replication to social units such as habits, routines and institutions, as pioneered by Veblen (1919), and revived many years later by Richard Nelson and Sidney Winter (1982) and others.

\section{References}


Anderson, Karl L. (1933) 'The Unity of Veblen's Theoretical System', Quarterly Journal of Economics, 47(4), August, pp. 598-626.

Archer, Margaret S. (1995) Realist Social Theory: The Morphogenetic Approach (Cambridge: Cambridge University Press).

Argyrous, George and Sethi, Rajiv (1996) 'The Theory of Evolution and the Evolution of Theory: Veblen's Methodology in Contemporary Perspective', Cambridge Journal of Economics, 20(4), July, pp. 475-95.

Bhaskar, Roy (1989) The Possibility of Naturalism: A Philosophic Critique of the Contemporary Human Sciences, 2nd edn. (Brighton: Harvester).

Bunge, Mario A. (1980) The Mind-Body Problem: A Psychobiological Approach (Oxford: Pergamon).

Campbell, Donald T. (1974) "Downward Causation" in Hierarchically Organized Biological Systems', in Ayala, Francisco J. and Dobzhansky, Theodosius (eds) (1974) Studies in the Philosophy of Biology (London, Berkeley and Los Angeles: Macmillan and University of California Press), pp. 179-86.

Commons, John R. (1934) Institutional Economics - Its Place in Political Economy (New York: Macmillan).

Darwin, Charles R. (1859) On the Origin of Species by Means of Natural Selection, or the Preservation of Favoured Races in the Struggle for Life, first edn. (London: Murray).

Dennett, Daniel C. (1995) Darwin's Dangerous Idea: Evolution and the Meanings of Life (London: Allen Lane).

Dewey, John (1910) The Influence of Darwin on Philosophy and Other Essays in Contemporary Philosophy (New York: Holt).

Dewey, John (1922) Human Nature and Conduct: An Introduction to Social Psychology, 1st edn. (New York: Holt).

Elster, Jon (1982) 'Marxism, Functionalism and Game Theory', Theory and Society, 11(4), pp. 453-82. Reprinted in Roemer, John E. (ed.) (1986) Analytical Marxism (Cambridge: Cambridge University Press).

Giddens, Anthony (1984) The Constitution of Society: Outline of the Theory of Structuration (Cambridge: Polity Press).

Hindess, Barry (1989) Political Choice and Social Structure: An Analysis of Actors, Interests and Rationality (Aldershot: Edward Elgar).

Hodgson, Geoffrey M. (1988) Economics and Institutions: A Manifesto for a Modern Institutional Economics (Cambridge and Philadelphia: Polity Press and University of Pennsylvania Press).

Hodgson, Geoffrey M. (1998) 'The Approach of Institutional Economics', Journal of Economic Literature, 36(1), March, pp. 16692. 
Hodgson, Geoffrey M. (2002) 'Darwinism in Economics: From Analogy to Ontology', Journal of Evolutionary Economics, 12(2), June, pp. 259-81.

Hodgson, Geoffrey M. (2003) 'The Hidden Persuaders: Institutions and Individuals in Economic Theory', Cambridge Journal of Economics, 27(2), March, pp. 159-75.

Hodgson, Geoffrey M. (2004) The Evolution of Institutional Economics: Agency, Structure and Darwinism in American Institutionalism (London and New York: Routledge) in press.

Huxley, Thomas Henry (1894) Collected Essays, 9 vols (London: Macmillan).

James, William (1890) The Principles of Psychology, 2 vols, 1st edn. (New York and London: Holt and Macmillan).

Kaldor, Nicholas (1985) Economics Without Equilibrium (Cardiff: University College Cardiff Press).

Kim, Jaegwon (1993) Supervenience and Mind (Cambridge and New York: Cambridge University Press).

Lachmann, Ludwig M. (1969) 'Methodological Individualism and the Market Economy', in Streissler, Erich W. (ed.) (1969) Roads to Freedom: Essays in Honour of Friedrich A. von Hayek (London: Routledge and Kegan Paul), pp. 89-103. Reprinted in Lachmann, Ludwig M. (1977) Capital, Expectations and the Market Process, edited with an introduction by W. E. Grinder (Kansas City: Sheed Andrews and McMeel).

Marshall, Alfred (1949) The Principles of Economics, 8th (reset) edn. (1st edn. 1890) (London: Macmillan).

Mayr, Ernst (1964) 'Introduction', in facsimile of the first edition of Darwin, Charles R. (1859) On the Origin of Species by Means of Natural Selection, or the Preservation of Favoured Races in the Struggle for Life (London: Murray), pp. vii-xxvii.

Mayr, Ernst (1988) Toward a New Philosophy of Biology: Observations of an Evolutionist (Cambridge, MA and London: Harvard University Press).

Mayr, Ernst (1992) One Long Argument: Charles Darwin and the Genesis of Modern Evolutionary Thought (London: Allen Lane).

Mises, Ludwig von (1949) Human Action: A Treatise on Economics (London: William Hodge).

Mitchell, Wesley C. (1924) 'The Prospects of Economics', in Tugwell, Rexford G. (ed.) (1924) The Trend of Economics (New York: Alfred Knopf), pp. 3-34. Reprinted in Mitchell (1937).

Murphree, Idus L. (1959) 'Darwinism in Thorstein Veblen's Economics', Social Research, 26(2), June, pp. 311-24.

Myrdal, Gunnar (1939) Monetary Equilibrium, translated from the Swedish edition of 1931 and the German edition of 1933 (London: Hodge). 
Nelson, Richard R. and Winter, Sidney G. (1982) An Evolutionary Theory of Economic Change (Cambridge, MA: Harvard University Press).

Ritchie, David G. (1896) 'Social Evolution', International Journal of Ethics, 6(2), pp. 165-81. Reprinted in Ritchie, David G. (1902) Studies in Political and Social Ethics (London and New York: Swan Sonnenschein and Macmillan) and Ritchie, David G. (1998) The Collected Works of D. G. Ritchie, ed. and introduced by Peter P. Nicholson (Bristol: Thoemmes), vol. 4.

Romanes, George John (1893) Darwin and After Darwin: An Exposition of the Darwinian Theory and a Discussion of PostDarwinian Questions, vol. 1, 2nd edn. (London: Longmans, Green).

Searle, John R. (1997) The Mystery of Consciousness (London: Granta Books).

Seckler, David (1975) Thorstein Veblen and the Institutionalists: A Study in the Social Philosophy of Economics (London: Macmillan).

Sober, Elliott (1981) 'Holism, Individualism, and the Units of Selection', in Asquith, P. D. and Giere, R. N. (eds) (1981) Philosophy of Science Association 1980, Vol. 2 (East Lansing, MI: Philosophy of Science Association), pp. 93-121. Reprinted in Sober, Elliott (ed.) (1984) Conceptual Issues in Evolutionary Biology: An Anthology (Cambridge, MA: MIT Press).

Sperry, Roger W. (1991) 'In Defense of Mentalism and Emergent Interaction', Journal of Mind and Behavior, 12(2), pp. 221-46.

Veblen, Thorstein B. (1898a) 'Why Is Economics Not an Evolutionary Science?', Quarterly Journal of Economics, 12(3), July, pp. 373-97. Reprinted in Veblen (1919).

Veblen, Thorstein B. (1898b) The Instinct of Workmanship and the Irksomeness of Labor', American Journal of Sociology, 4(2), September, pp. 187-201. Reprinted in Veblen (1934).

Veblen, Thorstein B. (1899) The Theory of the Leisure Class: An Economic Study in the Evolution of Institutions (New York: Macmillan).

Veblen, Thorstein B. (1900) 'The Preconceptions of Economic Science: III', Quarterly Journal of Economics, 14(2), February, pp. 240-69. Reprinted in Veblen (1919).

Veblen, Thorstein B. (1903) Review of Der moderne Kapitalismus by Werner Sombart, Journal of Political Economy, 11(2), March, pp. 300-5.

Veblen, Thorstein B. (1904) The Theory of Business Enterprise (New York: Charles Scribners).

Veblen, Thorstein B. (1908) 'Professor Clark's Economics', Quarterly Journal of Economics, 22(1), February, pp. 147-95. Reprinted in Veblen (1919). 
Veblen, Thorstein B. (1909a) 'Fisher's Rate of Interest', Political Science Quarterly, 24, June, pp. 296-303. Reprinted in Veblen (1934).

Veblen, Thorstein B. (1909b) 'The Limitations of Marginal Utility', Journal of Political Economy, 17(9), November, pp. 620-36. Reprinted in Veblen (1919).

Veblen, Thorstein B. (1914) The Instinct of Workmanship, and the State of the Industrial Arts (New York: Macmillan).

Veblen, Thorstein B. (1915) Imperial Germany and the Industrial Revolution (New York: Macmillan).

Veblen, Thorstein B. (1919) The Place of Science in Modern Civilization and Other Essays (New York: Huebsch).

Veblen, Thorstein B. (1934) Essays on Our Changing Order, ed. Leon Ardzrooni (New York: The Viking Press).

Young, Allyn A. (1928) 'Increasing Returns and Economic Progress', Economic Journal, 38(4), December, pp. 527-42. 